\title{
Clinical Research
}

\section{Incidence of venous thromboembolism among patients who underwent major surgery in a public hospital in Singapore}

\author{
Anindya P. Susanto, ${ }^{1}$ Charles Krisnanda, ${ }^{1}$ Doreen S-Y. Tan, ${ }^{2}$ Hean-Ye Ong, ${ }^{3}$ Dedy Pratama, ${ }^{1}$ Rasjid Soeparwata ${ }^{1}$ \\ ${ }^{1}$ Department of Surgery, Faculty of Medicine, Universitas Indonesia, Jakarta, Indonesia \\ ${ }^{2}$ Department of Pharmacy, Khoo Teck Puat Hospital, Singapore \\ ${ }^{3}$ Department of Cardiology, Khoo Teck Puat Hospital, Singapore
}

\begin{abstract}
Abstrak
Latar belakang: Tromboemboli vena (TEV) adalah salah satu komplikasi fatal tindakan bedah yang dapat dicegah. Pemberian tromboprofilaksis rutin masih menjadi perdebatan mengingat insiden TEV sangat kecil pada orang Asia. Penelitian ini bertujuan mengetahui insiden TEV dan pemberian tromboprofilaksis pada pasien yang menjalani tindakan bedah mayor di sebuah rumah sakit di Singapura.
\end{abstract}

Metode: Penelitian ini menggunakan metode potong lintang mengambil data dari 1.103 rekam medis pasien yang menjalani tindakan bedah mayor ortopedi dan digestif pada tahun 2011 dan 2012 di RS Khoo Teck Puat Singapura. Parameter penelitian adalah kejadian TEV selama perawatan atau rawat ulang dalam waktu satu bulan.

Hasil: Didapatkan insiden TEV sebesar 2,1\% (95\% CI: 1,67 - 2,53) yang terdiri dari 1,3\% dan 0,8\% trombosis vena dalam dan emboli paru. Umur, jenis kelamin, riwayat TEV sebelumnya, penyakit jantung iskemik, dan profilaksis mekanik mempunyai asosiasi dengan insiden TEV berdasarkan analisis bivariat. Pemberian tromboprofilaksis mempunyai asosiasi dengan riwayat penggunaan antikoagulan, jenis tindakan bedah, dan insiden pendarahan baru.

Kesimpulan: TEV merupakan komplikasi yang umum dari tindakan bedah mayor. Tromboprofilaksis farmakologis perlu dipertimbangkan seperti direkomendasikan dalam panduan non-Asia.

\begin{abstract}
Background: Venous thromboembolism (VTE) is a fatal yet potentially preventable complication of surgery. Routine thromboprophylaxis is still unequivocal prescription is problematic due to perception of low VTE incidence among Asian population. This study aims to investigate the incidence of VTE and thromboprophylaxis prescription among patients undergoing major surgery in a Singapore hospital.
\end{abstract}

Methods: This was a cross-sectional study. Data were obtained from medical record of 1,103 patients who had underwent major orthopaedic or abdominal surgery in 2011-2012 at Khoo Teck Puat Hospital, Singapore. Incidence of VTE events either in the same admission or re-admission in less than one month time were noted as study parameters.

Results: Incidence of VTE was $2.1 \%$ (95\% CI: 1.67 2.53 ) of which $1.3 \%$ and $0.8 \%$ were DVT and PE cases respectively. Age, gender, history of VTE, ischemic heart disease, and mechanical prophylaxis were associated with VTE incidence based on bivariate analysis. The prescription of pharmacological thromboprophylaxis was associated with prior anticoagulant medication, type of surgery, and incidence of new bleeding.

Conclusion: Subsequent to major surgeries, VTE is as common in Asian patients as published data in other populations. Pharmacologic thromboprophylaxis should be considered as recommended in non-Asian guidelines.

Keywords: thromboprophylaxis, venous thromboembolism

pISSN: 0853-1773• eISSN: 2252-8083・ http://dx.doi.org/10.13181/mji.v23i1.687 • Med J Indones. 2014;23:36-41

Correspondence author: Anindya P. Susanto, anindya.p.susanto@gmail.com

Copyright @ 2014 Authors. This is an open access article distributed under the terms of the Creative Commons Attribution-NonCommercial-ShareAlike 4.0 International License (http://creativecommons.org/licenses/by-nc-sa/4.0/), which permits unrestricted non-commercial use, distribution, and reproduction in any medium, provided the original author and source are properly cited. 
Venous thromboembolism (VTE), which comprises deep vein thrombosis (DVT) and pulmonary embolism (PE), is a serious medical event because it is potentially fatal. ${ }^{1}$ Earlier data shows $10-30 \%$ shortterm mortality rate following a VTE event, of which 20-25\% presents as PE-related sudden death., ${ }^{2,3}$ VTE is triggered by disturbance in homeostatic system induced by vessel wall injury, stasis of blood flow, and hypercoagulable state. ${ }^{4}$ Hospitalisation in major surgeries, including orthopaedic and abdominal surgeries, have been identified as one of VTE risk factors. ${ }^{5,6}$ One out of eight fatal cases of PE occurs in post-operative patients. ${ }^{7}$ Other prominent risk factors include past VTE event and malignancy.

In view of VTE fatality, evidence-based recommendations for the routine use of prophylaxis against VTE subsequent to major surgery have been proposed. ${ }^{8,9}$ In Asia, this practice is yet far from ideal as there is perception that the incidence of VTE among Asians tends somewhat to be lower compared to Caucasians, which is also pointed out by a local study. ${ }^{10}$ Reports over last two decades have confronted this view by showing that the incidence of post-operative VTE in Asian patients is not a rarity with wide variations of incidence rate. ${ }^{11}$ Recent large epidemiological study in Asian centres, which included a Singaporean centre, demonstrated a VTE incidence rate of $2.3 \%$ (99\% CI: 1.6-3.2). ${ }^{12}$

This paper reports a cross-sectional study investigating the incidence of post-operative venous thromboembolic events in Khoo Teck Puat Hospital (KTPH) Singapore, the extent of mechanical and pharmacological thromboprophylaxis prescription, as well as the evaluation the risk of bleeding in patients receiving recommended thromboprophylaxis. This data will serve as an evidence for future hospital internal guidelines in order to manage this preventable fatal condition.

\section{METHODS}

This was a cross-sectional study of all patients who underwent major orthopaedic and abdominal surgeries at Khoo Teck Puat Hospital, Singapore in year 2011 and 2012. This project defines total knee replacement, total hip replacement, and hip fracture surgery as major orthopedic surgeries, as described in earlier papers. Abdominal surgeries include open and laparotomy surgeries of abdominal wall, abdominal cavity, colorectal, and gastrectomy, in which they have been associated with postoperative VTE events. Data were collected based on the electronic database of patients who underwent surgical and orthopedic surgery in Khoo Teck Puat Hospital. Baseline demographic data were collected together with anthropometric measures and serum creatinine level as standard of care prior to surgery. Patient's medical history and comorbidities, such as ischemic heart disease, congestive cardiac failure, stroke, cancer, and previous VTE, were also noted. Subsequently, post-surgical prescription of VTE mechanical prophylaxis, VTE pharmacological thromboprophylaxis, confirmed new bleeding events, length of hospital stay, and mortality were recorded. Pharmacological thromboprophylaxis was defined as the prescription of Enoxaparine 60 mg bd.

The primary study endpoint was the incidence of VTE events either in the same admission or readmission in less than one month period. If $\mathrm{PE}$ and DVT were detected concomitantly, the case was regarded as PE since PE is a complication of DVT with fatal clinical implication. VTE events were identified by the summary of clinical conditions validated by radiology examination.

Statistical analysis utilises SPSS 17. Association of factors in categorical data were analysed using chi-square method. Fischer test and KolmogorovSmirnov were performed for $2 \times 2$ table and $\mathrm{R} \times$ 2 table respectively whenever chi-square method criteria cannot be fulfilled. Numeric data of nonparametric variable were compared by MannWhitney test.

\section{RESULTS}

Data from a total of 1,103 subjects who underwent major orthopedic and abdominal surgeries in 20112012 were involved in this study (Table 1). The study population consisted of $481(43.6 \%)$ men and 622 $(56.4 \%)$ women with median age of 65 years old. Majority of the subject were Chinese (76.2\%). There were more subjects who went through orthopaedic $(57.9 \%)$ as compared to abdominal surgery $(42.1 \%)$. Pharmacological thrombophylaxis was given in 112 subjects $(10.2 \%)$.

This project detected 23 cases of VTE (Table 2), which results in incidence rate of $2.1 \%$ (95\% CI $1.67-2.53)$. There were 14 cases $(1.3 \%)$ of clinically symptomatic DVT and 9 cases $(0.8 \%)$ of diagnosed PE with or without DVT detected. All cases were confirmed by radiological findings. 
Table 1. Background characteristics of study population ( $\mathrm{n}=$ $1,103)$

\begin{tabular}{lc}
\hline Variables & Result \\
\hline Age, median (range) & $65(16-109)$ \\
Gender, n (\%) & \\
\hline Male & $481(43.6 \%)$ \\
\hline Female & $622(56.4 \%)$ \\
\hline Race, no (\%) & \\
\hline Chinese & $841(76.2 \%)$ \\
\hline Indian & $67(6.1 \%)$ \\
\hline Malay & $159(14.4 \%)$ \\
\hline Others & $36(3.3 \%)$ \\
\hline BMI, median (kg/m²) & 23.85 \\
\hline CrCl, median (mL/min) & 69.68 \\
\hline Type of surgery, no (\%) & \\
\hline Orthopedic surgery & $639(57.9 \%)$ \\
\hline Abdominal Surgery & $464(42.1 \%)$ \\
\hline Prophylaxis, no (\%) & $112(10.2 \%)$ \\
\hline Stockings (knee) & $536(48.6 \%)$ \\
\hline Stockings (thigh) & $12(1.1 \%)$ \\
\hline Clexane & \\
\hline BMI $\%$ body mass ing & \\
\hline
\end{tabular}

$\mathrm{BMI}=$ body mass index, $\mathrm{CrCl}=$ creatinine clearance

Table 2. Incidence of VTE

\begin{tabular}{cccc}
\hline Incidence & $\begin{array}{c}\text { Orthopedic } \\
\text { surgery }\end{array}$ & $\begin{array}{c}\text { Abdominal } \\
\text { surgery }\end{array}$ & Total (\%) \\
\hline VTE & $18(2.8 \%)$ & $5(1.1 \%)$ & $23(2.1 \%)$ \\
PE & $9(1.4 \%)$ & 0 & $9(0.8 \%)$ \\
DVT & $9(1.4 \%)$ & $5(1.1 \%)$ & $14(1.3 \%)$ \\
\hline
\end{tabular}

$\mathrm{PE}=$ pulmonary embolism, $\mathrm{DVT}=$ deep vein thrombosis

Incidence of VTE is highest in the geriatric population older than 75 years old (Table 3 ). Age group division in this study follows earlier study. Female $(2.7 \%)$ has higher incidence rate compared to male $(1.2 \%)$. Among patients who have prior history of VTE, half of them were found to have VTE subsequent to their surgeries with strong statistical significance $(p<0.001)$. Patients with history of stroke also had increased likelihood to have DVT, although it was not statistically significant. In addition, this study demonstrated that past medical history of ischemic heart disease was strongly associated with incidence of VTE after surgery.
Table 3. Distribution of background characteristics in patients with and without VTE $(\mathrm{n}=1,103)$

\begin{tabular}{|c|c|c|c|}
\hline & $\begin{array}{c}\text { Non-VTE } \\
\mathrm{n}(\%)\end{array}$ & $\begin{array}{l}\text { VTE } \\
\text { n (\%) }\end{array}$ & $\mathrm{p}$ \\
\hline Age group & & & 0.008 \\
\hline$<60$ year old & $376(98.9)$ & $4(1.1)$ & \\
\hline $60-75$ year old & 407 (98.5) & $6(1.5)$ & \\
\hline$>75$ year old & $297(95.8)$ & $13(4.2)$ & \\
\hline Gender & & & 0.087 \\
\hline Male & $475(98.8)$ & $6(1.2)$ & \\
\hline Female & $605(97.3)$ & $17(2.7)$ & \\
\hline History of VTE & & & $<0.001$ \\
\hline Yes & $4(50)$ & $4(50)$ & \\
\hline No & $1076(97.8)$ & $19(2.1)$ & \\
\hline Cancer & & & 0.501 \\
\hline Yes & $118(99.2)$ & $1(0.8)$ & \\
\hline No & $962(97.8)$ & $22(2.2)$ & \\
\hline Stroke & & & 0.658 \\
\hline Yes & $70(97.2)$ & $2(2.8)$ & \\
\hline No & $1010(98)$ & $21(2.0)$ & \\
\hline Heart failure & & & 1.000 \\
\hline Yes & $20(100)$ & $0(0)$ & \\
\hline No & $1060(97.9)$ & $23(2.1)$ & \\
\hline Ischemic heart disease & & & 0.031 \\
\hline Yes & $83(94,3)$ & $5(5.7)$ & \\
\hline No & $997(98.2)$ & $3(1.8)$ & \\
\hline Type of surgery & & & 0.286 \\
\hline TKR & $284(98.3)$ & $10(1.7)$ & \\
\hline THR & $104(97.2)$ & $0(2.8)$ & \\
\hline HFS & $233(95.9)$ & $5(4.1)$ & \\
\hline Abdominal wall & $130(100)$ & $0(0)$ & \\
\hline Abdominal cavity & $159(97)$ & $5(3.0)$ & \\
\hline Colorectal & $123(100)$ & $0(0)$ & \\
\hline Gastrectomy & $47(100)$ & $0(0)$ & \\
\hline Mechanical prophylaxi & & & 0.052 \\
\hline Yes & $530(97.1)$ & $16(2.9)$ & \\
\hline No & $550(98.7)$ & $7(1.3)$ & \\
\hline \multicolumn{2}{|c|}{ Pharmacological prophylaxis } & & 0.281 \\
\hline Yes & $108(98.1)$ & $4(1.9)$ & \\
\hline No & $972(96.4)$ & $19(3.6)$ & \\
\hline
\end{tabular}

$\mathrm{TKR}=$ total knee replacement, THR $=$ total hip replacement, $\mathrm{HFS}=$ hip fracture surgery

The use of thromboprophylaxis is associated with prior history of warfarin medication in less then 2 months, type of surgery, and incidence of new bleeding after prophylaxis given (Table 4). Seven out of 9 patients $(77.8 \%)$ who received warfarin previously were given thromboprophylaxis subsequent to their surgeries. Gastrectomy patients 
Table 4. Factors associated with the use of pharmacological thromboprophylaxis

\begin{tabular}{|c|c|c|c|}
\hline & $\begin{array}{c}\text { Prophylaxis not given } \\
\text { n (\%) }\end{array}$ & $\begin{array}{c}\text { Prophylaxis given } \\
\mathrm{n}(\%)\end{array}$ & $\mathrm{p}$ \\
\hline History of VTE & $5(62.5)$ & $3(37.5)$ & 0.039 \\
\hline Cancer & $92(77.3)$ & $27(22.7)$ & $<0.001$ \\
\hline Stroke & $64(88.9)$ & $8(11.1 \%)$ & 0.781 \\
\hline Heart failure & $16(80)$ & $4(20.0)$ & 0.137 \\
\hline Ischemic heart disease & $69(78.4)$ & $19(21.6)$ & $<0.001$ \\
\hline Warfarin $(<2 \mathrm{mo})$ & & & $<0.001$ \\
\hline Yes & $2(22.2)$ & $7(77.8)$ & $<0.001$ \\
\hline No & $989(90.4)$ & $105(9.6)$ & \\
\hline Type of surgery & & & $<0.001$ \\
\hline TKR & $280(96.9)$ & $9(3.1)$ & \\
\hline THR & $101(94.4)$ & $6(5.6)$ & \\
\hline HFS & $221(90.9)$ & $22(9.1)$ & \\
\hline Abdominal wall & $128(98.5)$ & $2(1.5)$ & \\
\hline Abdominal cavity & $142(86.6)$ & $22(13.4)$ & \\
\hline Colorectal & $91(74)$ & $32(26.0)$ & \\
\hline Gastrectomy & $28(59.6)$ & $19(40.4)$ & \\
\hline Bleeding & & & 0.020 \\
\hline Yes & $27(77.1)$ & $8(22.8)$ & \\
\hline No & $964(90.3)$ & $104(9.7)$ & \\
\hline
\end{tabular}

$\mathrm{TKR}=$ total knee replacement, $\mathrm{THR}=$ total hip replacement, HFS $=$ hip fracture surgery

were given tromboprophylaxis most frequently (40.4\%) compared the other type of surgery, with abdominal wall surgeries $(1.5 \%)$ being the least. New bleeding event occurred more in patients who received thromboprophylaxis compared to patients who did not receive prophylaxis.

Table 5 study demonstrated that the occurrence of VTE will prolong patients' hospital stay significantly. Of 23 VTE cases, death occurred in 3 cases in which all are PE cases.

Table 5. Outcome associated with VTE cases

\begin{tabular}{lccc}
\hline & $\begin{array}{c}\text { Non- VTE } \\
\mathrm{n}(\%)\end{array}$ & $\begin{array}{c}\text { VTE } \\
\mathrm{n}(\%)\end{array}$ & $\mathrm{p}$ \\
\hline $\begin{array}{l}\text { Median length of } \\
\text { stay (days) }\end{array}$ & 6 & 16 & $<0.001$ \\
Mortality & & & 0.002 \\
$\quad$ Yes & $9(75)$ & $3(25)$ & \\
No & $1071(98.2)$ & $20(1.8)$ & \\
\hline
\end{tabular}

\section{DISCUSSION}

One of the problems in post-operative patients undergoing major surgery is the incidence of VTE. In Asian countries, the guideline based practice of pharmacological prophylaxis is under-utilized due to the perception of lower incidence of VTE in Asian populations compared to Western. ${ }^{10}$

This study highlighted that the incidence of VTE in Asian population is not low. In the Western population, CHEST guideline had estimated a combined 35-day untreated baseline risk of symptomatic VTE incidence of $4.3 \% .^{8}$ In our study, apart from the use of mechanical prophylaxis (49\%) and pharmacological prophylaxis $(10 \%)$, the incidence of VTE is still high (2.1\%).

The multicentre SMART study in Asian countries showed the low utilization of several mechanical prophylaxis $(6.3 \%)$ and pharmacological prophylaxis $(2.2 \%)$ and had also reported comparable incidence of VTE in postoperative orthopedic surgery $(2.3 \%) .{ }^{12}$ 
However, another Singaporean studies by $\mathrm{Ng}$, et al ${ }^{14}$ showed that the incidence of VTE appeared to be lower $(0.96 \%)$. The probable explanation for this Singapore based disparity may refer to the number of the population observed.

Several risk factors were shown to be significantly associated with the incidence of VTE in this study were older age group ( $>75$ year old), history of previous VTE, and history of ischemic heart disease. This findings are relevant with the studies in either Western or Asian populations., ${ }^{2,14-16}$ In addition, orthopaedic surgery significantly increased the incidence of acquiring VTE compared to abdominal surgery $(2.8 \%$ vs $1.1 \%$, respectively; $p<0.05)$ consistant with data from other studies. ${ }^{14,17}$

This study demonstrated that pharmacological prophylaxis did not have an association with a reduction in the incidence of VTE. However, this may be biased as surgeons do pre-scribeprophylaxis based on their subjective clinical judgement of risk factors. Based on our data, proposed risk factors associated with the surgeon's subjective prescription of pharmacological prophylaxis are previous medical history of ischemic heart disease, cancer, and VTE, prior use of warfarin, and type of surgery.

Major hindrance for the prescription of pharmacological prophylaxis for VTE in postoperative patients is bleeding. Albeit there is higher incidence of bleeding in our study, there is still a need to consider the role of pharmacological prophylaxis administration because of high related mortality and morbidity in our VTE patient.

Mortality of $25 \%$ was reported along with the increase morbidity, illustrated in terms of hospital stay, up to 10 days in patients with VTE. The utilization of best mean prophylaxis (mechanical and pharmacological) is highly recommended to prevent the fatality of VTE. This study therefore affirms that the use of prophylaxis is imperative in order to reduce unwanted clinical outcome.

There are some limitations of this study. First, this is a single centre study and may not represent the general phenomenon in Singapore and Asia. Second, this study uses cross-sectional method that could not demonstrate the true relationship between the prescription of thromboprophylaxis and incidence of VTE as the surgeon's unblinded subjective clinical judgement may have affected the prescription pattern. A randomised, blinded, controlled study is needed to describe to be performed in order to prove the relationship.

In conclusion, this single-centre study demonstrated VTE incidence of $2.1 \%$ in Asian patients undergoing major orthopaedic and abdominal surgeries and is as common as data from Western population. Age, gender, history of VTE, ischemic heart disease, and mechanical prophylaxis are significant risk factors associated with VTE. The incidence of VTE leads to longer hospital stay and increases shortterm mortality. Pharmacologic thromboprophylaxis continue to be essential, particularly in patients with potential risk factors.

\section{Acknowledgment}

This project is part of medical elective posting in Khoo Teck Puat Hospital Singapore as a result of joint cooperation between Faculty of Medicine Universitas Indonesia, Yong Loo Lin School of Medicine National University of Singapore, and Temasek Foundation.

\section{Conflict of interest}

The authors declare that this study is free of conflict of interest.

\section{REFERENCES}

1. Sule AA, Chin TJ, Sinnathamby L, Lee HK, Earnest A. A cohort study to analyze the risk of venous thromboembolism mortality in patients admitted to the General Medicine Department, Tan Tock Seng Hospital, Singapore. Int J Angiol. 2011;20(2):87-94.

2. Cushman M, Tsai AW, White RH, Heckbert SR, Rosamond WD, Enright P, et al. Deep vein thrombosis and pulmonary embolism in two cohorts: The longitudinal investigation of thromboembolism etiology. Am J Med. 2004;117(1):19-25.

3. Heit JA, Silverstein MD, Mohr DN, Petterson TM, O'Fallon WM, Melton LJ 3rd.. Predictors of survival after deep vein thrombosis and pulmonary embolism: A population-based, cohort study. Arch Intern Med. 1999;159(5):445-53.

4. Cross MB, Boettner F. Pathophysiology of venous thromboembolic disease. Seminars in Arthroplasty. 2009;20(4):210-6.

5. Huerta C, Johansson S, Wallander MA, García Rodríguez LA. Risk factors and short-term mortality of venous thromboembolism diagnosed in the primary care setting in the United Kingdom. Arch Intern Med. 2007;167(9):935-43.

6. Al Sayegh F, Almahmeed W, Al Humood S, Marashi M, Bahr A, Al Mahdi H, et al. Global risk profile verification in patients with venous thromboembolism (GRIP 
VTE) in 5 Gulf countries. Clin Appl Thromb Hemost. 2009;15(3):289-96.

7. Laporte S, Mismetti P, Décousus H, Uresandi F, Otero $\mathrm{R}$, Lobo JL, et al. Clinical predictors for fatal pulmonary embolism in 15,520 patients with venous thromboembolism: findings from the Registro Informatizado de la Enfermedad TromboEmbolica venosa (RIETE) Registry. Circulation. 2008;117(13):1711-6.

8. Falck-Ytter Y, Francis CW, Johanson NA, Curley C, Dahl OE, Schulman S, et al. Prevention of VTE in orthopedic surgery patients: antithrombotic therapy and prevention of thrombosis, 9th ed. American College of Chest Physicians Evidence-Based Clinical Practice Guidelines. Chest. 2012;141(2 Suppl):e278S-325S.

9. Liew NC, Chang YH, Choi G, Chu PH, Gao X, Gibbs $\mathrm{H}$, et al. Asian venous thromboembolism guidelines: prevention of venous thromboembolism. Int Angiol. 2012;31(6):501-16.

10. Molina JAD, Gabriel ZJ, Bee HH, Ong BKC. Venous thromboembolism at the National Healthcare Group, Singapore. Ann Acad Med Singapore. 2009;38(6):470-8.
11. Liew NC, Moissinac K, Gul Y. Postoperative venous thromboembolism in Asia: a critical appraisal of its incidence. Asian J Surg. 2003;26(3):154-8.

12. Leizorovicz A, Turpie AGG, Cohen AT, Wong L, Yoo MC, Dans A, et al. Epidemiology of venous thromboembolism in Asian patients undergoing major orthopedic surgery without thromboprophylaxis. The SMART study. J Thromb Haemost. 2005;3(1):28-34

13. Sakon M, Maehara Y, Yoshikawa H, Akaza H. Incidence of venous thromboembolism following major abdominal surgery: a multi-center, prospective epidemiological study in Japan. J Thromb Haemost. 2006;4(3):581-6.

14. Ng HJ, Lee LH. Trends in prevalence of deep venous thrombosis among hospitalised patients in an Asian institution. Thromb Haemost. 2009;101(6):1095-9.

15. White RH. The epidemiology of venous thromboembolism. Circulation. 2003;17;107(23 Suppl 1):I4-8.

16. Anderson FA, Spencer FA. Risk factors for venous thromboembolism. Circulation. 2003;107:19-16.

17. Agnelli G. Prevention of venous thromboembolism in surgical patients. Circulation. 2004:110:IV4-12. 